\title{
TEORIAN JA KÄYTÄNNÖN JÄNNITE
}

\section{tutkimusta, koulutusta ja kehittämistyötä integroivassa täydennyskoulutuksessa}

\author{
Tutkijoiden ja ammattilaisten vuorovaikutus koulutuksessa \\ on perustaltaan jännitteinen prosessi. Jännitteet liittyvät \\ teoreettisen ja käytånnöllisen tiedon eroihin ja vuorovaiku- \\ tuksen osapuolten tiedontarpeisiin.
}

Tamperelaisten ja jyväskylålåisten työelämän tutkijoiden projektissa "Tutkimus - koulutus - kehittåminen" tutkijoiden ja käytännön ammattilaisten vuorovaikutus synnytetään täydennyskoulutuksen välityksellä. Haasteena on etsiä siltoja tutkimuksen, koulutuksen ja kehittåmistyön välille.

Artikkeli tarkastelee oppimisprosessin näkökulmasta tieteen ja käytännön vuorovaikutusta. Oppimisprosessin yksilötasoinen analyysi tuotti viisi erilaista ihmistyyppiä, joiden odotuksia ja asenteita koulutukseen artikkelissa selostetaan. Kirjoittaja toteaa työelämän organisaatioiden suosivan instrumentaalista ja vastustavan emansipatorista oppimista.

Työn humanisointiteeman virittämä laaja yhteiskunnallinen keskustelu työelämän laa. dusta teollistuneissa länsimaissa nosti yhteiskuntatieteellisen ja psykologisen tutkimuksen aallonharjalle 1970-luvulla. Tutkijoilla oli merkittävä rooli julkisen keskustelun teemo. jen muotoilijoina. Huomion keskipisteeseen nostettiin työn sisällön ja haasteiden kehittäminen ja osallistumismuotojen luominen työpaikkatasoiseen vaikuttarniseen. Tutkijat liikkuivat vahvalla maaperällä vielä siinä vaiheessa, kun kyse oli yleisten suuntaviivojen hahmottelusta työn uudelleenorganisoinnil. le.

Askeleen ottaminen työpaikkatasoisen kehittämistoiminnan suuntaan oli huonom- min pohjustettu. Tutkijayhteisön sisäinen keskustelu ei ollut kunnolla käynnistynyt kysymyksestä, onko ja pitäisikö tutkijoilla olla käsitteiden kehittämisen lisäksi jokin rooli keinojen etsimisessä työelämän laadun konkreettiseen kehittämiseen.

Työelämän tutkimuksessa on sittemmin kehitetty lähestymistapoja, jotka pyrkivät kuromaan umpeen välimatkaa sosiaalitieteilijöiden inhimillisen työvoiman käyttöä koskevista opeista käytännön kehittämistoimintaan. Itseäni ovat kiinnostaneet erityisesti sellaiset lähestymistavat, joissa tutkijoiden panos on tukemassa organisaatioissa tapahtuvaa omaehtoista kehittämistä. Kiinnostus on kul. jettanut maastoon, jossa työelämän tutki- 
muksen ja aikuiskoulutusta koskevan tutkimuksen alueet leikkaavat toisiaan.

Esimerkiksi OD-strategia (Organization development, esim. French \& Bell 1973, Honkanen 1989), pohjoismaisten tutkijoiden kehittämä demokraattisen dialogin lähestymistapa (esim. Gustavsen \& Engelstad 1986, Gustavsen 1987) ja Suomessa jalansijaa saanut kehittävä työntutkimus (esim. Engeström 1985, Engeström 1987, Toikka 1984) pyrkivät kukin löytämään sellaisen vuorovaikutussuhteen tutkijoiden ja organisaation jäsenten välille, joka stimuloi ongelmien yhteistä pohdintaa ja kehittämisvaihtoehtojen etsimistä.

Yhteistä mainituille lähestymistavoille on työelämän uudistumisprosessien tarkastelu oppimiskäsitteen kautta ja koulutuksen näkeminen keinona luoda organisaation uudistumisessa välttämätöntä henkistä liikkuma. alaa.

Joukko tamperelaisia ja jyväskyläläisiä työelämän tutkijoita on käynnistänyt toimintaa, jossa tutkijoiden ja käytännön ammattilaisten vuorovaikutus synnytetään täydennyskoulutuksen välityksellä. Tutkimushaasteena on etsiä siltoja tutkimuksen, koulutuksen ja kehittämistyön välille. Suomen Akatemia on tukemassa toimintaa kesällä 1990 solmimansa tutkimussopimuksen "Tutkimus - koulutus - kehittäminen" kautta (Kirjonen ym. 1990). Pohjatyötä hankkeelle on tehty Tampereen yliopistossa vuonna 1986.87 toteutetun työtieteellisen täyden. nyskoulutusohjelman ja sitä seuranneen arviointityön yhteydessä (esim. Filander ym 1990). Tässä julkaistava "The 2nd international congress for research on activity theory, Lahti 1990" kongressissa pidettyyn esitel. mään pohjaava artikkeli osa kyseistä arviointityötä. (Esitys on pidetty, vähäisin painatuseroin, myös Korkeakoulutuksen tutkimuksen IV symposiumissa Jyväskylässä 1990.) Artikkeli tarkastelee oppimisprosessin näkökulmasta tieteen ja käytännön vuorovaikutusta.

\section{Viitekehys}

Tutkijoiden ja ammattilaisten vuorovaikutus koulutuksessa on perustaltaan jännitteinen prosessi. Jännitteet liittyvät teoreettisen ja praktisen tiedon eroihin ja vuorovaikutuksen osapuolten tiedon tarpeisiin. Sekä ammattityötä että koulutusta koskevan tutkimuksen alueelta löytyy analyyseja, jotka auttavat näkemään, millaisesta kitkasta erilaa- tuisen tiedon kohtaamistilanteessa on kysy. mys.

Schön (1983) on tutkinut ammattilaisten tietämisen tapoja, kohdentaen huomion erityisesti tiedepohjaisiin ammatteihin. Hän lähestyy asiaa tarkastelemalla työtilanteita, joissa ammattilaisen on pysähdyttävä pohdiskelemaan. Tällaisia reflektiota vaativia tilanteita esiintyy esimerkiksi silloin, kun eteentuleva ilmiö on outo tai hän ei kykene muuntamaan ongelmaa hallittavaksi tai asetetut vaatimukset ovat yhteensopimattomia tai epäjohdonmukaisia. Reflektio edellyttää näissä tapauksissa tutkivaa lähestymistapaa, tilanteen keskustelevaa kohtaamista. Erityinen tunnusmerkki hänen tietämisentaval. leen on se, että hän on itse tilanteessa, jota pyrkii ymmärtämään. Lopullinen testi ymmärtämiselle on, että hän kykenee tekemään jotakin ongelmalliselle tilanteelle. Uusi ymmärrys voi syntyä asettamalla ongelma uuteen viitekehykseen tai käyttämällä esimerkkejä tai metaforia, jotka auttavat synnyttämään uusia havaintoja ja selityksiä.

Tutkimus voi myötävaikuttaa ammattilaisen reflektioon tuottamalla uutta esimerkkiaineistoa, samoin kuin tuottamalla tietoa siitä uudelleenstrukturointitapahtumasta, jossa tieteellinen teoria toimii ammattilaisen antaman selityksen virikkeenä ja pohjana. Tutkijan ja ammattilaisen vuorovaikutuksessa am. mattilainen ei toimi pelkkänä tutkimustuloksen käyttäjänä. Ne teoriat ja metodit, joita hän käyttää, ovat hänen henkilökohtaisia konstruktioitaan, joiden kautta hän suhteuttaa uutta ennestään tuntemaansa.

Pohjoismaissa kehitelty osallistuva tutkimuskäytäntö (esim. Elden ja Taylor 1983, Gustavsen ja Engelstad 1986, Sandberg 1983) on kiinnittänyt erityistä huomiota tutkijoideri ja organisaation jäsenten väliseen vuorovaikutukseen. Avainkäsite lähestymistavassa on demokraattinen dialogi. Lähestymistavan edustajat katsovat, että dialogi on yhteisen oppimisen tilanne, jossa osanottajilla on toisiaan täydentävää tietoa. Ulkopuolisella asiantuntijalla on yleistä teoreettista tietoa ja tietoa muutoksen läpiviemisestä; työntekijöillä on konkreettista tietoa asioiden ja tapahtumien kytkennöistä omalla työpaikalla. Yhdessä asianosaisten kanssa tutkija voi auttaa identifioimaan syy-seuraussuhteita. Dialogin tulos kiteytyy nk. paikallisessa teoriassa, joka tekee organisaation spesifin tilanteen ymmärrettäväksi.

Kolb'n (1984) epistemologinen tarkastelu kokemustiedon ja teoreettisen tiedon eroista 
johdattaa näkemään, mitä tutkijoiden ja ammattilaisten toisiaan täydentävän tiedon kohtaaminen voisi merkitä koulutuksessa. Kolb haluaa korostaa kokemustiedon ja abstraktin käsitteellisen tiedon rinnakkaisuutta. Ne eivät ole hierarkkisessa suhteessa toisiinsa, vaan avaavat laadullisesti erilaisia näkökulmia maailmaan. Hän näkee, että käsitteiden hankkimisessa kokemuksilla on olennainen sija ja käsitteet muuttuvat kokemusten myötä. Hänen mukaansa oppiminen on jännitteitä ja konflikteja sisältävä prosessi, jossa uutta tietoa, taitoja ja asenteita hankitaan neljän oppimismuodon vuorottelun ja vastakkaina. settelun kautta: konkreetin kokemuksen kautta, jossa oppijat antautuvat vastaanottamaan uusia kokemuksia; reflektiivisen tarkkailun kautta, jossa he tarkkailevat kokemuksiaan eri näkökulmista; abstraktin käsitteel. listämisen kautta, jossa he luovat uusia käsitteitä integroimaan havainnoinnin tulokset loogisesti pitäviksi teorioiksi; aktiivisen kokeilun kautta, jossa he käyttävät näitä teorioita tehdessään päätöksiä ja ratkaistessaan ongelmia.

Kun Kolb kohdentaa huomion yksilöön ja henkilöhistoriaan sitoutuvaan kokemustietoon, organisaatiotasoista oppimista käsitelleet tutkijat ovat tarkastelleet kollektiivisessa toiminnassa kumuloituvaa tietoa (esim. Argyris \& Schön 1978). Organisaation muistiin on kasautunut tietoa, joka käsittelee toimintaperiaatteita, tarkoitusta, työsuorituksen teknisiä yksityiskohtia ja ylipäänsä menneitä kokemuksia, jotka toimivat tulevan toiminnan esimerkkeinä. Organisatorisessa oppimisessa tätä tietovarastoa laajennetaan tai jä. sennetään uudella tavalla. Yksilöllinen oppiminen vaikuttaa organisaatiotasoiseen oppimiseen silloin, kun yksilön tiedosta tulee jaettua tietoa. Meidän on ymmärrettävä am. mattilaisen tieto tiedoksi organisaatiotasoisen tiedon määrittämissä puitteissa. Organisaatiotasoisella tiedolla on taipumus rajata olennaisten asioiden piiri ja vaikuttaa siihen, mitkä asiat ovat avoimia keskustelulle, ky. seenalaistamiselle ja uusien näkökulmien asettamiselle.

Työyhteisön ulkopuolella annattavaan koulutukseen osallistuvien henkilöiden oppimistarpeet voivat olla hyvin erilaisia; heillä voi olla yleisluontoisesti asetettu itsensä sivistämisen tavoite, halu ymmärtää paremmin ympäröivää maailmaa, pyrkimys laajentaa näkökulmaansa omaa työtä tai työyhteisöä koskevissa asioissa tai tavoite löytää ratkaisuja tiettyihin tarkasti määriteltävissä oleviin työongelmiin. Mikään koulutus ei vastaa sa- malla painolla kaikkiin tämänkaltaisiin tavoitteisiin ja odotuksiin, vaikka periaatteessa koulutus voi palvella samanaikaisesti useampia oppimistarpeita. Koulutuksen relevanssi voi näyttäytyä erilaisena eri osanottajille riippuen siitä, mitä yksilöllisen ja kollektiivisen toiminnan aluetta sen odotetaan edistävän.

Oppimisessa muokkautuu sekä suhde omaan itseen että ympäröivään maailmaan. Mezirovin $(1981,1985)$ käsitteet instrumentaalisesta, dialogisesta ja itsereflektiivisestä oppimisesta valaisevat tätä oppimistarpeiden ja tehtävien moninaisuutta. Mezirovin mukaan instrumentaalinen oppiminen tähtää tehtäväsuuntautuneeseen ongelmanratkaisuun, joka on relevanttia pyrittäessä hallitsemaan ympäröivää maailmaa. Sellaisen tiedon tuotannossa hypoteettis-deduktiiviset teoriat ovat osoittautuneet hedelmällisiksi. Kun päämääränä on oppia ymmärtämään merkityksiä, jotka vaikuttavat kanssakäymiseemme muiden ihmisten kanssa, dialogissa esiintulevien ilmiöiden analyysi ja merkitys. skeemojen tarkastelu metaforien kautta ovat sopivia tapoja tuottaa tietoa. Itsereflektio tuottaa tietoa, joka auttaa tulemaan tietoiseksi sellaisista kulturaalisista ja psykologista oletuksista, jotka rajoittavat mahdollisuuksia nähdä, ajatella tai toimia vaihtoehtoisilla tavoilla.

Jos nyt palaamme Kolbin kokemusperäisen oppimisen malliin, voimme havaita, että pedagogisena mallina se sallii erilaisten oppimistehtävien läsnäolon oppimisprosessissa ja rohkaisee käyttämään erilaisia tiedon tuotta. misen tapoja. Sellaisenaan se ei implikoi mutta ei myöskään sulje pois Mezirovin tarkoittamaa itsereflektiivistä oppimista.

\section{Tutkimustehtåvå}

Analyysi kohdentuu valtionhallinnon henkilöstölle suunnattuun koulutukseen ja siinä hyödynnetään erilaisten oppimistehtävien ja niihin liittyvien tietämisen tapojen näkökulmaa. Suomessa on tapahtumassa merkittäviä muutoksia valtionhallinnossa. Muutostilanteiden hallinta edellyttää syvällistä näkemystä nykyisestä tilanteesta sen kehityshistoriaa vasten ja perusteltuja tulevaisuuteen suuntaavia näköaloja. Koulutuksen tarkoituksena oli edesauttaa ymmärryksen syntymistä tieteellisen tiedon ja tutkimustehtäviä sisältävän opiskelun kautta. Valtionhallinnon todellisuus oli läsnä koulutuksessa sekä sisällöllisenä asiana että kontekstina: sisällöllisenä siinä mielessä, että ohjelmaan sisältyi 
muun aineiston ohella myös spesifisti valtionhallintoa käsittelevää aineistoa; kontekstina tarjoamalla käsitteellistämisen raamit ja oppimisympäristön koulutettaville. Kuvaus käsittelee oppimistuloksia ja -prosessia sekä kurssikohtaisesti että yksilöllisesti.

\section{Aineisto}

Tampereen yliopiston täydennyskoulutus järjesti vuonna 1986-87 nk. työtieteellisen ohjelman ja 1988 ohjelmaan sisältyvän seurantaseminaarin. Tarkoituksena oli tarjota tietoa ja käynnistää oppimisprosessi, joka edistäisi valtionhallinnossa meneillään olevien muutosten ymmärtämistä. Monitieteisen ohjelman suunnittelussa ja toteuttamisessa oli mukana psykologiaa, sosiaalipsykologiaa, sosiologiaa, sosiaalipolitiikkaa ja hallintotie. teitä edustavia tutkijoita. Ohjelma välitti työ. elämän tutkimukseen pohjaavaa tietoa makro-, organisaatio- ja yksilötasoisista ilmiöistä. Sisällöllinen aines muokattiin tutkimusperinteitä yhdistäväksi teemarakenteeksi seuraavien neljän teeman mukaisesti: 1) työelämän muutosprosessi ja tiedontuotanto, 2) työn kehittäminen ja suunnittelu, 3) työn organisointi ja ohjaus, 4) työn sosiaaliset, psyykkiset ja terveydelliset seurausvaikutukset.

Koulutukseen valittiin 24 valtionhallinnon keskijohdossa ja asiantuntijatehtävissä toimivaa osanottajaa, jotka joutuivat vastaamaan edustamissaan organisaatioissa tai niiden tehtäväalueella tapahtuvien muutosten suunnittelusta tai toimeenpanosta. Osanottajajoukko oli omasi näin ollen moniammatillinen ja vaihtelevan koulutuspohjan. Pääosalla oli ylempi korkeakoulututkinto, viidellä oli alempi korkeakoulu- tai keskiasteen tutkinto. Yhden vuoden sisällä toteutettuun ohjelmaan kuului viisi koulutusjaksoa ja jaksojen välillä suoritettavia opiskelutehtäviä. Koulutuksen pedagogiset ratkaisut mukailivat Kolbin kokemusperäisen oppimisen kehään sisältyvää mallia. Omassa työssä kohdattavien ongelmien käsittely ryhmätöissä, abstraktia käsitteellistämistä tukevien luentojen ja kirjallisen aineiston läpikäyminen ja tietojen soveltaminen omaa työtä taị organisaatiota koskevaan harjoitustyöhön etenivät ohjelmassa rinnakkain.

Ohjelma tavoitteli eri tasoilla syntyvän dialogin rikastuttamaa ja muokkaamaa koulutustapahtumaa; vuorovaikutusta viritettiin eri aloja edustavien tieteenharjoittajien kesken, tutkijoiden ja osallistujien kesken, eri virastoja ja ammattialoja edustavien ammatinhar. joittajien kesken ja osanottajien ja heidän työyhteisönsä kesken. Tiedon aktiivisessa ja omakohtaisessa jäsentelyssä harjoitustyöllä oli keskeinen sija.

Oppimisprosessin kuvaukseen on käytettävissä kur'ssilaisten jokaisen jakson kuluessa laatimat arviot, heidän harjoitustyönsä eri versiot ja muut kirjalliset työt. Sen lisäksi on opettajien verbaaliset arviot suunnitteluryh. mässä ja kirjoittajan omat arviot opettajan ja osallistuvan havainnoijan roolissa.

\section{Tulokset}

\section{Koulutuksen eteneminen ja arviot vaikutuksista}

Virastoihin lähetettiin etukäteen tiedote, joka kuvasi koulutuksen tavoitteita ja työskentelymetodeja. Tiedote pani painoa käsitteelliselle työskentelylle, mutta se on voinut luoda myös instrumentaalisen hyödyntämisen odotuksia kytkemällä koulutuksen valtionhallinnon muutostapahtumiin.

Osanottajien koulutukseen kohdistamat odotukset vaihtelivat alun alkaen: itsensä sivistäminen, ajattelun virkistäminen, asioiden tarkastelu teorian läpi, näköalojen avartaminen, etäisyydenotto omaan työhön, ratkaisujen etsiminen ja neuvojen saaminen päiväkohtaisiin työongelmiin kuvaavat odotusten kirjoa. Joillakuilla osanottajilla työyhteisöstä käsin tulevat paineet saivat ilmauksensa odotuksissa, jotkut toiset katsoivat omaavansa suhteellisen vapauden määritellä oppimis. tavoitteet. Odotuksen määrittelyissään osanottajat ilmaisivat epäsuorasti myös käsityksiään tiedosta ja oppimisprosessista. Nämä käsitykset tulivat täsmällisemmin esille koulutuksen kuluessa.

Koulutuksen keskeinen idea ja metodi eivät auenneet osanottajille mitenkään itsestäänselvästi. Arviointilomakkeista on luetta. vissa useamman jakson ajan jonkinasteista hämmennystä siitä, mitä tarjottu koulutus on perimmäiseltä luonteeltaan. Hämmennys purkautui aluksi koulutuksen pedagogisiin ratkaisuihin suunnattuna kritiikkinä. Vähitellen osanottajat alkoivat pohtia myös omaa suhdettaan koulutukseen. Tieteen- ja ammatinharjoittajien keskinäistä dialogia painottava koulutusmetodi ei tarjonnut valmista tietoa ja valmiita ratkaisuja osanottajien työ. ongelmiin. Vasta tällaisista odotuksista irtaantuminen antoi tietä aktiiviselle opiskeluorientaatiolle, jota tiedon omakohtainen 
työstäminen edellyttää. Oman oppimisprosessin analysoinnissa ryhmän keskinäisellä keskusteluilla oli tärkeä sija. Niissä pohdittiin $\mathrm{mm}$. tiedon hyödyntämisen erilaisia aspekte. ja. Samoin pohdittiin koulutuksen roolia pait. si tiedon välittäjänä, myös väylänä oppia op. pimaan.

Koulutuksen vaikutuksiksi (taulukko 1) voidaan lukea osallistujien mainitsemat näköalojen avartuminen, uudet ideat koskien oman työn organisointia, kiinnostuksen suuntautuminen uusille alueille ja harkinnan lisääntyminen omissa ratkaisuissa. Näiden kognitiivisten tulosten ohella koulutus viritti toimintaa, joka liittyi suoraan tai välillisesti organisaation kehittämistyöhön: kirjoittelua oman harjoitustyön teemasta, opintopiireihin osallistumista, ideoiden soveltamista työryh. missä tai käynnissä olevissa laajemmissa ke. hitysprojekteissa, tutkimuksen käynnistämistä. (Heiskanen 1990a, Filander ym. 1990).

Oppimistuloksena perspektiivien laajene. minen ja omaa työyhteisöä koskevien muu. tospaineiden näkeminen laajemmasta viite. kehyksestä on koulutusohjelmalle asetettujen tavoitteiden suuntainen. Oppimisprosessien yksilötasoinen analyysi paljastaa, miten se vastaa osanottajien tavoitteita.

\section{Oppimisprosessit tyyppikuvauksen valossa}

Oppimisprosessien yksilötasoinen analyy. si (Heiskanen 1990b) tuotti viisi tyyppiä, jotka nimesin käytännön kehittäjäksi, reflektiiviseksi soveltajaksi, sivistyjäksi, uusien pers. pektiivien aktiiviseksi hakijaksi ja teoreettisesti ymmärrettyyn käytäntöön pyrkijäksi. Tyyppien muodostamisessa kiinnitin huomiota sekä osanottajien yleiseen opiskeluorientaatioon että heidän tapaansa käsitellä tietoa ja asettaa ongelmia.

Oppimisprosessien analyysissa sain vaikutteita oppimisstrategia- ja tiedon proses. sointitutkimuksista (esim. von Wright ym. 1979, Marton \& Säljö 1984), kuitenkin painottaen tyypillisiä oppimisstrategiatutkimuksia enemmän kontekstia, jossa oppimistarve syntyy ja uusi tieto otetaan käyttöön.

\section{Henkillo̊ A: Käytånno̊n kehittåjä.}

Henkilö A:n oppimistavoitteet olivat, Mezirovin terminologiaa käyttääksemme, instrumentaaliset. Hän odotti koulutukselta käytännön neuvoja, jotka auttaisivat häntä päivittäisen työn suorittamisessa. Hän hyötyi ehkä vähiten koulutuksesta. Läpi ohjelman hänellä oli tunne, että koulutus ei tarjonnut sitä apua ja sellaisia vastauksia, joita hän oli etsimässä. Hänen sitoutumisensa koulutukseen oli vähäinen ja hänen kiinnostuskynnyksensä oli korkea sekä luentojen että ryhmätöiden suhteen. Kuitenkin harjoitustyötä hän piti varauksettomasti hyödyllisenä. Artikkeliarvioissa, joita oli määrä tehdä koulutusjaksojen välillä, hän ei esittänyt omakohtaista kommentointia. Määritellessään ongelmia ja etsiessään vaihtoehtoisia ratkaisuja hän luotti enemmän kokemuksen kuin tieteellisen tutkimuksen tuottamaan tietoon. Hänen mielestään tieteenharjoittajat ja käy. tännön ihmiset eivät kohtaa, koska tutkijat ovat liian kaukana käytännöstä.

Henkilö B:n, joka edustaa myös "kåytänno̊n kehittåjäa"-tyyppiä, ristiriitaisia oppimistavoitteita suuntasivat vahvasti hänen omasta työyhteisöstään tulevat paineet. Hänen ihanteensa työelämän kehittämisen suunnista ja hänen näkemyksensä kehittämisen reunaehdoista olivat vaikeasti yhteensovitettavissa. Hänen oppimistavoitteensa olivat myös instrumentaalisia siinä mielessä, että hän olisi halunnut panna oppimansa vä. littömästi käytännön palvelukseen.

Kuitenkin hän erosi henkilö A:sta siinä, millaista tietoa ja ymmärrystä hän etsi. Sovellutuspuolella hän otti kontekstin ja ongelmanasettelun annettuina, mutta toisaalta jotkut hänen pyrkimyksensä viittaavat yrityksiin ymmärtää ilmiöitä tavalla, joka ylittäisi annetut ongelmanasettelut. Hän oli ilmeisen pettynyt, että ohjelma ei tarjonnut hänelle välitöntä apua käytännön työongelmiin. Hänen tapauksessaan tyytymättömyys ei ollut kuitenkaan samalla osoitus vähäisestä sitoutumisesta. Hän paneutui vakavissaan harjoitustyöhön ja näki koulutuksen periaatteellisella tasolla merkitykselliseksi. Kuitenkin voimakas käytännön tiedon painotus, jota hän ilmaisi sekä kirjallisissa töissä että keskuste. luissa, ja epäluottamus teoreettisen tiedon mahdollisuuksiin, ylläpitivät ristiriitojen leimaamaa opiskeluorientaatiota.

\section{Henkilö C: Reflektiivinen soveltaja}

Henkilö $C$ oli asettanut itselleen käytännölliset päämäärät, mutta samalla hän oli myös etsimässä uusia arvoja. Hänen harjoitustyönsä liittyi läheisesti hänen välittömiin työtehtäviinsä. Ongelmanasettelutapa tähtäsi kuitenkin ongelmien näkemiseen vaihtoehtoisella tavalla. Näkökulmat ja sisällölliset asiat, joita kurssi tarjosi, olivat hänelle uusia. Hänellä oli määrätietoinen pyrkimys saada 
ote uudesta sisältöaineksesta. Esimerkiksi kirja- ja artikkeliarvioissa hän pohti kirjoitta. jan pyrkimyksiä, tekstin yleistä merkitystä, tutkimustyön luotettavuutta, ehdotettujen ideoiden kantavuutta ja auki jääviä kysymyk siä. Hän kykeni hyödyntämään sekä teoreettista ainesta että ryhmäkeskustelujen antia. Hänen vastaanottavaisuutensa erilaiselle tie. dolle mahdollisti sen, että hänen omat käytännön kokemuksensa tulivat reflektoitaviksi useista eri näkökulmista. Yleisarviona ohjelmasta hän esitti, että kurssi oli laajentanut hänen näkökulmaansa ja saanut hänet nä. kemään yleisten mallien tärkeys erilaisten tilanteiden analysoinnissa.

\section{Henkilö D: Sivistyjä.}

Henkilö D:n tapauksessa yleisen sivistymisen tavoite oli tärkeämmällä sijalla kuin välittömät tiedon hyödyntämisodotukset. Hän oli kiinnostunut oppimaan uusia asioita ja ym. märtämään erilaisia näkökulmia. Esimerkiksi kirja- ja artikkeliarvioissa henkilö D pohti tekstien taustaa ja niiden liittymistä laajem. piin kokonaisuuksiin, kirjoittajan tavoitteita sekä tekstin ja johtopäätösten tieteellistä painoarvoa. Hänen harjoitustyönsä käsitteli teoreettisten mallien hedelmällisyyttä työelämän muutosten arvioinnissa. Hän piti antoisina myös ryhmäkeskusteluja, joissa käsiteltiin toisten osanottajien töitä. Kaiken kaikkiaan hän oli sekä analyyttinen että kriittinen arvioidessaan saamaansa tietoa.

\section{Henkilö E: Uusien perspektiivien aktiil- vinen etsijä.}

Henkilö E oli ensisijaisesti kiinnostunut kohottamaan tietämystään työelämän kysymyksistä ja avartamaan näkemyksiään. Ohjelmassa käsitellyt lähestymistavat olivat hänelle pääasiassa uusia. Tätä hän piti etuna, sillä hän tahtoi kyseenalaistaa sen paradigman, joka määrittää nykyiset käsitteet hänen edustamallaan hallinnonalalla ja etsiä vaih. toehtoisia tapoja nähdä asioita. Hän suhtautui kaikkiin opiskelutehtäviin vakavasti. Hän alkoi seurata uusia aikakauslehtiä jo ohjelman kuluessa. Ohjelman päättymisen jälkeen hän jatkoi opiskelua itsenäisesti ja osallistui työpaikalla perustetun opintopiirin toimintaan. Hänen harjoitustyönsä lopullinen versio ja hänen arvionsa vuosi ohjelman päättymisen jälkeen lähetetyssä seurantaky. selyssä osoittavat merkkejä, joita voisi kutsua Mezirovin tarkoittamaksi perspektiivitransformaatioksi. Hänen tapauksessaan se ei ollut yhtäkkinen muutos vaan hidas prosessi. Esimerkiksi hänen laatimansa kirja- ja artikkeliarviot olivat pikemminkin kuvailevia kuin analyyttisiä, kuuluen oppimisvaiheeseen, jossa uuden perspektiivin rakennusaineet eivät olleet vielä löytäneet paikkaansa.

Henkilö F: Teoreettisesti ymmärrettyyn kåytänto̊ön pyrkijä.

Henkilö F odotti oppivansa koulutuksessa työelämän kehitysilmiöistä ja saavansa haltuunsa käsitteitä, jotka auttaisivat häntä ymmärtämään syvällisemmin empiirisiä ilmiöitä. Hän oli kiinnostunut erilaisista oppimistavoista ja erilaisten näkökulmien ja lähestymista. pojen merkityksestä ongelmien hahmottamisessa. Harjoitustyössään hän pani tämän kiinnostuksen testattavaksi soveltamalla eri tieteenalojen tietoa ja näkökulmia tutkimusongelmansa taustoittamiseen. Hän oli vastaanottavainen sekä toisten osanottajien kokemuksille että luentojen ja kirjallisuuden kautta välittyvälle tiedolle, ottaen siihen samalla kriittistä etäisyyttä. Hän käytti tekstejä ja muuta informaatiota uusien ideoiden lähteenä, kehitellen niitä eteenpäin.

\section{Keskustelu}

Monitieteinen ohjelma ei tarjonnut osanottajille yhtenäistä teoreettista viitekehystä, vaan pikemminkin ajattelun välineitä ja vaihtoehtoisten viitekehysten rakennuspuita aktiiviselle etsijälle.

Tietyn tyyppisen tiedon relevanssi vaihtelee yksilöllisten oppimistarpeiden mukaan.Osanottajat, joiden oppimispäämäärät olivat ensisijaisesti instrumentaalisia, pitivät koulutusta vähemmän antoisana kuin ne osanottajat, jotka asettivat itselleen yleisiä sivistymistavoitteita tai jotka etsivät uusia virikkeitä ajatteluunsa. "Käytännön kehittäjille" teoreettinen aines oli liian etäällä käytännön ongelmista, joihin he olivat hakemassa neuvoja ja ratkaisuja. Heidän orientaatiolleen oli tyypillistä epäilevä suhtautuminen ylipäänsä teoreettista tietoa kohtaan.

"Reflektiivinen soveltaja" asetti itselleen samanaikaisesti erilaisia oppimistavoitteita, jotka edellyttivät sekä instrumentaalista, dialogista että itsereflektiivistä oppimista. Hänen tapauksessaan kiinnekohta ja tiedon relevanssin testi oli hänen oma työnsä.

Samoin kuin "reflektiivisellä soveltajalla" myös "teoreettiseen käytäntöön pyrkijällä" vastaanottavaisuus erityyppiselle tiedolle oli merkillepantavaa. Heidän oppimisprosessissaan oli silti myös olennaisia eroja. "Teoreettiseen käytäntöön pyrkijällä" pääpaino oli teoreettisella puolella. Hän pyrki näkemään työongelmia laajemmissa yhteyksissä ja ylit- 
tämään perinteiset tai annetut ongelmanasettelut, hyödyntäen tässä pyrkimyksessä tieteellisten teorioiden tarjoamia näkökulmia. "Reflektiivinen soveltaja" ei kyseenalaistanut samassa määrin kontekstia.

"Uusien perspektiivien aktiivinen etsijä" painotti myös koulutuksen teoreettista antia. Hänen keskeinen kiinnostuksen kohteensa oli tarkastella organisaation toiminnan perus. tavia oletuksia ja etsiä uusia näkökulmia. Hänellä, samoin kuin "sivistyjällä" linkki takaisin työtodellisuuteen jäi esimerkinomaiseksi. Tässä suhteessa he erosivat esimerkiksi "te. oreettisesti ymmärrettyyn käytäntöön pyrkijästä", joka palasi toistuvasti käytännön kysymyksiin otettuaan niihin ensin teoreettisten pohdiskelujen kautta välimatkaa.

Oppijat olivat itse sisällä tilanteessa eli valtionhallinto oli heille samalla sekä oppimis- ympäristö että pohdiskelevan tarkkailun tionhallinto oli heille samalla sekä oppimisympäristö että pohdiskelevan tarkkailun kohde. Organisaatiot sosiaalistavat jäsenensä tietynlaiseen organisaatiota koskevaan itseymmärrykseen, eikä mikään organisaatio ole täysin avoin tiedolle, joka koskee sen omaa toimintaa. Schön (1983) on ilmaissut asian sanomalla, että organisaatioilla on taipumus vastustaa ammattilaisen pyrkimyksiä siirtyä teknisestä asiantuntijuudesta reflektiiviseen. Tämä huomautus johdattaa meidät lopuksi korostamaan yksilöllisten oppimistarpeiden kollektiivisia kiinnekohtia. Organisaatiot pyrkivät suosimaan instrumentaalista op. pimista ja vastustamaan emansipatorista oppimista - huomautus, jonka myös jotkut koulutuksen osanottajat tekijät. Kysymys tiedon relevanssista sisältää samanaikaisesti ky. symyksen yksilöstä ja kollektiivista, vaikka painopiste vaihtelee tapauskohtaisesti.

\section{LÄHTEET}

Argyris C \& Schön D 1978. Organizational learning: A theory of action perspective. Addison-Wesley Publishing Company, Massachusetts.

Brookfield S 1986. Understanding and facilitating adult learning, a comprehensive analysis of principles and effective practice, Open University Press, USA

Elden M \& Taylor J C 1983. Participatory research at work: an introduction. Journal of Occupational Behaviour, Vol. 4, 1-8

Engeström Y 1985. Kehittävän työntutkimuksen peruskäsitteitä, Aikuiskasvatus 4/85, 156-164

Engeström Y 1987. Learning by expanding, An activity-theoretical approach to developmental research, Orienta-Konsultit Oy, Helsinki

Filander K \& Heiskanen T \& Kirjonen J 1990. Tutkimuksen ja koulutuksen strategiavalinnat työelämän kehittämisessä. English Summary. Tampereen yliopisto, Työelämän tutkimuskeskus, Yhteiskuntatieteiden tutkimuslaitos, Sarja T. Tampere

French W L \& Bell C H 1973. Organisaation kehittäminen. Weilin \& Göös, Helsinki

Gustavsen B 1987. Reformer på arbetsplatsen och demokratisk dialog, kirjassa Jan
Odhnoff-Casten von Otter (red): Arbetets rationaliteter, Om framtidens arbetsliv, 25-46, Arbetslivscentrum, Stockholm

Gustavssen B \& Engelstad P H 1986. The design of conferences and the evolving role of democratic dialogue in changing working life. Human Relations 39, 2, 101-116

Heiskanen T 1990a. Influencing organizational change: Evaluation of a university-level educational programme, kirjassa Haslegrave C M, Wilson J R, Nigel E \& Manenica I (eds) Work design in practice, 202-206, Taylor \& Francis, London

Heiskanen T 1990b. Organizational change in public administration, Evaluating an extension training programme for public administrators, unpublished manuscript.

Honkanen 1989. Organisaation ja työyhteisön kehittäminen, suuntauksia ja menetelmiä, Työterveyslaitos, Katsauksia 106

Kirjonen J, Heiskanen T, Filander K \& Haakana A 1990. Tutkimus - koulutus - kehittäminen. Tieteidenvälinen tutkimus- ja koulutusohjelma. Tutkimussuunnitelma, Suomen Akatemia

Kolb D A 1984. Experiential learning. Experience as the source of learning and development. Prentice-Hall Inc., Englewood Cliffs 
Marton F \& Säljö R 1984. Approaches to learning. In Marton F, Hounseil P \& Entwistle N (eds) The experience of learning, 36-55, Scottish Academy Press, Edinburgh

Mezirov J 1981. A critical theory of adult learning and education. Adult Education Volume 32, $13-24$

Mezirov J 1985. A critical theory of self-directed learning. New Directions for Continuing Education N:o 25, 17-30

Schön D 1983. The reflective practitioner, How professionals think in action. Basic Books, Inc.,Publishers, New York
Sandberg $\AA$ 1983. Trade union -orientated research for democrartization of planning in work life -problems and potentials. Journal of Occupational Behaviour, Vol 4, 59-71

Toikka K 1984. Kehittävä kvalifikaatiotutkimus. Valtion koulutuskeskuksen julkaisusarja B/25, Valtion painatuskeskus, Helsinki

von Wright J , Vauras M \& Reijonen P 1979. Oppimisen strategiat kouluiässä I, Psykologian tutkimuksia, No 33, Turun yliopisto, Turku 


\section{AIKUISKASVATUS}

The Finnish Journal of Adult Education

Vol.10, 4/90

ISSN 0358-6197

Summary

Heiskanen, Tuula 1990. Teorian ja käytännön jännite tutkimusta, koulutusta ja kehittä. mistyötä integroivassa koulutuksessa.

- Tutkijoiden ja ammattilaisten vuorovaikutus koulutuksessa on perustaltaan jännitteistä. Työelämän tutkijoiden projektissa luo. daan vuorovaikutusta täydennyskoulutuksen välityksellä. Yhteistyöosapuolena on valtionhallinnon henkilöstö. Artikkelissa kerrotaan projektin tuloksista, arvioidaan koulutuksen etenemistä ja sen vaikutusta sekä kuvataan erilaisia ihmistyyppejä oppimisprosessin kannalta.

Aikuiskasvatus 10,4.
Heiskanen, Tuula 1990. The tension of theory and practice in training integrating research, training and development.

- In training, the interaction between researchers and professionals is basically charged with tension. In this project involving researchers in worklife, interaction is created via further training. The collaborating party consists of the government administration personnel. The article reports on the findings of the project, estimates the progress of the training and its effects and the various personality types from the point of view of the learning process.

Aikuiskasvatus 10,4. 